\title{
Awareness and attitudes toward corneal donation: challenges and opportunities
}

This article was published in the following Dove Press journal:

Clinical Ophthalmology

\author{
Andrew MWilliams' \\ Kelly W Muir ${ }^{2,3}$ \\ 'Department of Ophthalmology, \\ University of Pittsburgh Medical \\ Center, Pittsburgh, PA, USA; \\ ${ }^{2}$ Department of Ophthalmology, Duke \\ University Medical Center, Durham, \\ NC, USA; ${ }^{3}$ Durham VA Medical \\ Center, Health Services Research and \\ Development, Durham, NC, USA
}

\begin{abstract}
There is a severe shortage of donor corneas available worldwide for transplantation, with the number of patients in need of transplant greatly exceeding the number of cornea tissues available. Understanding awareness and attitudes about corneal donation worldwide is a critical step toward addressing this shortage. In this review, awareness of corneal donation and reported willingness to donate are summarized from 55 published studies across 13 countries. In general, many more respondents indicated positive attitudes toward eye donation and willingness to donate their eyes than the number of respondents who have pledged their eyes for donation, suggesting an unrealized potential of additional donors. Specifically, of 38,851 respondents across all included studies, $52 \%$ endorsed a willingness to donate their eyes after death, yet only $5 \%$ reported being a pledged donor. The most commonly cited reason for not being a registered eye donor was lack of awareness about eye donation. The disconnection between the large number of people who expressed willingness to donate and the scarcity of individuals who have pledged their eyes for donation could be addressed through educational media campaigns, collaborations with medical personnel, partnerships with grief counselors and religious leaders, use of social media, and educational sessions with medical students and staff.
\end{abstract}

Keywords: eye donation, corneal transplantation, attitudes, eye bank, organ donation

\section{Introduction}

Blindness from corneal opacity is a significant public health burden that is estimated to affect 1.5 million persons and accounts for about $4 \%$ of cases of blindness worldwide. ${ }^{1}$ A disproportionate share of corneal blindness falls on Asia, where estimates of corneal blindness in China have ranged from 10 to $15 \%$ of all blindness. ${ }^{2,3}$ Similarly, the Andhra Pradesh Eye Disease Study in India found the prevalence of corneal blindness to be $0.13 \%$, which constituted $9 \%$ of all blindness. ${ }^{4}$

Corneal transplantation is an effective treatment option for many patients with corneal disease, with a high success rate in restoring sight. Unfortunately, a major limiting factor in performing corneal transplants is availability of donor tissue, especially in Asian nations. ${ }^{5}$ A recent global survey of eye banking and corneal transplantation quantified the drastic mismatch between supply and demand of donor corneas worldwide, finding only 1 cornea available for every 70 needed. ${ }^{6}$ The shortage of available corneal tissue highlights the importance of exploring limiting factors in corneal donation worldwide. The purpose of this review is to examine awareness and attitudes about corneal donation worldwide and to use this information to identify possible interventions to increase rates of cornea donation. 


\section{Methods}

A nonlanguage-restricted search of the literature was conducted for publications from any date in the PubMed/ MEDLINE and Google Scholar databases. Search terms included "eye donation," "cornea donation," "attitudes AND awareness AND eye donation," "interventions AND eye OR cornea donation," and "attitudes OR awareness OR interventions AND eye OR cornea OR organ donation." Abstracts were reviewed for relevance. References of included papers were also reviewed for further sources. Out of 127,712 initial results from the literature search, 330 articles were screened for relevance based on title or abstract. In total, 55 articles were found to meet inclusion criteria for this review. See Figure 1 for a flow chart of article selection.

\section{Awareness of corneal donation worldwide and willingness to donate}

We identified 55 studies that have evaluated awareness of corneal donation across the world, with methods ranging from surveys to door-to-door interviews (Table 1). Over half of these studies come from India, where the shortage of cornea tissue for transplant is particularly severe. ${ }^{4}$ Nations represented in this review include Australia, ${ }^{7}$ China, ${ }^{8-10}$ Ethiopia, ${ }^{11-13}$ Ghana, ${ }^{14}$ India, ${ }^{15-45}$ Malaysia, ${ }^{46,47}$ Nepal, ${ }^{48,49}$ Nigeria, ${ }^{50-53}$ Pakistan, ${ }^{54,55}$ Saudi Arabia, ${ }^{56,57}$ Singapore, ${ }^{58,59}$ Turkey, ${ }^{60}$ and the United States. ${ }^{61}$ Study populations include eye patients, family members of eye patients, general community populations, adolescents, university students, physicians, and medical or health science students. In total, these studies have surveyed or interviewed a total of 38,851 people about awareness or willingness to donate their eyes after death.

While the methods vary widely between studies, particularly in survey design and question wording, general themes can be summarized. Awareness of corneal donation ranged from $8.4 \%$ among eye patients in Ghana to $100 \%$ among a sample of medical students in India, ${ }^{14,44}$ averaging $71 \%$ across all included studies. Willingness to donate ranged from $7.3 \%$ among surveyed urban Pakistanis to $90 \%$ of patients at a tertiary eye institute in the United States, ${ }^{55,61}$ averaging 52\% across all studies. Of note, these figures may be artificially high as social desirability bias may lead some respondents to give an untruthful positive response. Even among studies with a large percentage expressing willingness to donate their eyes after death, the actual number who have pledged their eyes for donation ranged only from $0.1 \%$ to $11 \%,{ }^{49,61}$ averaging $5 \%$ between all studies, indicating a disconnect between having an interest in eye donation and registering as an eye donor (Table 1$)$.

\section{Factors associated with awareness and willingness to donate}

Several characteristics have been associated with willingness to donate eyes. One factor is race. Among a United States population, white race compared to black race was associated with higher rates of willingness to consider donation. ${ }^{61}$ Among Singaporean adults, ethnic Chinese were significantly

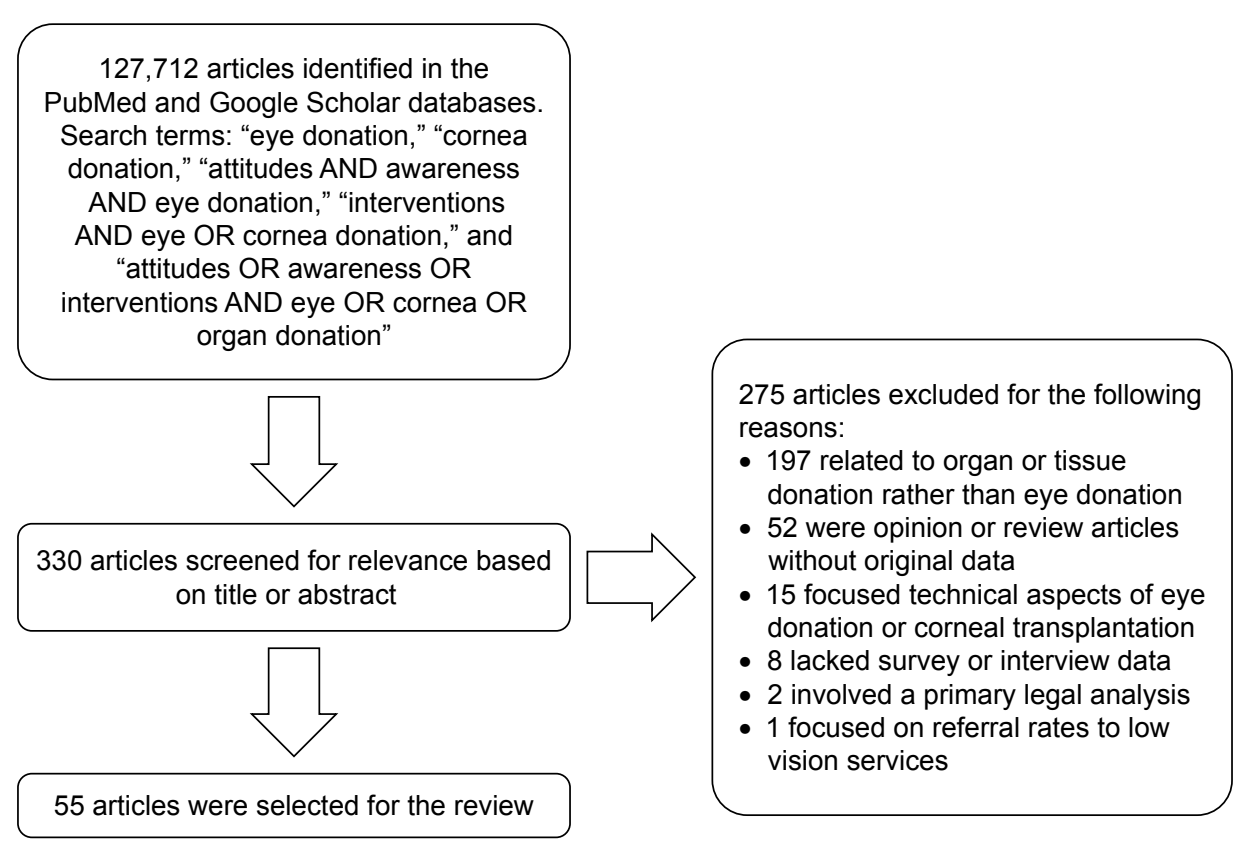

Figure I Flow chart of article selection. 
Table I Awareness of corneal donation and willingness to donate across 55 included studies

\begin{tabular}{|c|c|c|c|c|c|c|c|}
\hline$\overline{\text { Study }}$ & Country & Subjects & Method & $\begin{array}{l}\text { Awareness } \\
(\%)\end{array}$ & $\begin{array}{l}\text { Willingness } \\
\text { to donate (\%) }\end{array}$ & $\begin{array}{l}\text { Pledged } \\
\text { donors (\%) }\end{array}$ & Comments \\
\hline Lawlor et al ${ }^{7}$ & Australia & 371 adults & Survey & & 59 & & \\
\hline Chu et $\mathrm{al}^{8}$ & China & $\begin{array}{l}\text { I,867 registered tissue } \\
\text { donors and I,796 resident } \\
\text { controls }\end{array}$ & Survey & $\begin{array}{l}90.3 \text { (registered } \\
\text { tissue donors); } \\
78.9 \text { (resident } \\
\text { controls) }\end{array}$ & $\begin{array}{l}82.2 \text { (registered } \\
\text { tissue donors); } \\
45.1 \text { (resident } \\
\text { controls) }\end{array}$ & & \\
\hline Wang et al ${ }^{9}$ & China & $\begin{array}{l}430 \text { adults in } 12 \text { randomly } \\
\text { chosen communities in } \\
\text { Guangzhou, southern China }\end{array}$ & Survey & & 40.7 & & \\
\hline Zhao et al ${ }^{10}$ & China & $\begin{array}{l}\text { I,072 residents of } \\
\text { Chongqing, China }\end{array}$ & Survey & & 47.2 & 9.51 & $\begin{array}{l}62.69 \% \\
\text { supported eye } \\
\text { donation }\end{array}$ \\
\hline $\begin{array}{l}\text { Gelaw and } \\
\text { Ambaw"1 }\end{array}$ & Ethiopia & $\begin{array}{l}403 \text { health science students } \\
\text { and academic university staff }\end{array}$ & Survey & 81.8 & & & \\
\hline $\begin{array}{l}\text { Gessesse and } \\
\text { Tilahun }^{12}\end{array}$ & Ethiopia & $\begin{array}{l}492 \text { adults in sampled } \\
\text { housing units }\end{array}$ & Interview & 30.9 & 57.9 & & \\
\hline Hussen et $\mathrm{al}^{13}$ & Ethiopia & $\begin{array}{l}774 \text { community-dwelling } \\
\text { adults }\end{array}$ & Interview & 57 & 38 & & \\
\hline $\begin{array}{l}\text { Ackuaku-Dogbe } \\
\text { and Abaidoo' }\end{array}$ & Ghana & $\begin{array}{l}536 \text { eye patients at a } \\
\text { tertiary center }\end{array}$ & Survey & 8.4 & 59.9 & & \\
\hline Acharya et al ${ }^{15}$ & India & $\begin{array}{l}208 \text { medical and nonmedical } \\
\text { staff of a tertiary eye } \\
\text { institute in New Delhi }\end{array}$ & Survey & 65.9 & 84.6 & & \\
\hline Ahirwar et al ${ }^{16}$ & India & 467 medical students & Survey & 81.4 & 61.9 & & \\
\hline Amruth et $\mathrm{al}^{17}$ & India & $\begin{array}{l}25 \mathrm{I} \text { adult patients and their } \\
\text { attendants at a primary } \\
\text { health center in south India }\end{array}$ & Survey & 36.6 & 51 & & \\
\hline Biswas et $\mathrm{al}^{18}$ & India & $\begin{array}{l}\text { I,525 secondary school } \\
\text { students }\end{array}$ & Survey & 81 & & & \\
\hline Chacko et al ${ }^{19}$ & India & $\begin{array}{l}100 \text { adolescents at a pre- } \\
\text { university college }\end{array}$ & Survey & 70.5 & & & \\
\hline Dandona et $\mathrm{al}^{20}$ & India & $\begin{array}{l}2,522 \text { urban adults of } \\
\text { Hyderabad, India }\end{array}$ & Interview & 73.8 & 44.9 & 1.9 & \\
\hline Dhaliwal $^{21}$ & India & $\begin{array}{l}49 \text { final-year medical } \\
\text { students and } 24 \text { non-medical } \\
\text { students of comparable age } \\
\text { (controls) }\end{array}$ & Survey & $\begin{array}{l}79.6 \text { (medical } \\
\text { students), } \\
87.5 \text { (controls) }\end{array}$ & $\begin{array}{l}83.7 \text { (medical } \\
\text { students), } \\
87.5 \text { (controls) }\end{array}$ & & \\
\hline Duggal et $\mathrm{a}^{22}$ & India & $\begin{array}{l}2,000 \text { adult residents of } \\
\text { northwest India }\end{array}$ & Interview & 70.5 & 52 & & \\
\hline Gupta et $\mathrm{a}^{23}$ & India & $\begin{array}{l}188 \text { first- and second-year } \\
\text { nursing students in } \\
\text { Bangalore }\end{array}$ & Survey & 96.8 & 85.1 & & \\
\hline Gupta et $\mathrm{al}^{24}$ & India & $\begin{array}{l}365 \text { students between } \\
\text { seventh and tenth grade }\end{array}$ & Survey & 87 & 36 & & $\begin{array}{l}72 \% \text { supported } \\
\text { or strongly } \\
\text { supported } \\
\text { cornea donation }\end{array}$ \\
\hline Khan et $\mathrm{a}^{25}$ & India & $\begin{array}{l}\text { I } 54 \text { outpatients at a tertiary } \\
\text { hospital }\end{array}$ & Survey & 86 & 61 & & \\
\hline $\begin{array}{l}\text { Khandelwal and } \\
\text { Katre }^{26}\end{array}$ & India & $\begin{array}{l}300 \text { healthcare providers at } \\
\text { a tertiary care hospital }\end{array}$ & Survey & 91 & 74.7 & & \\
\hline $\begin{array}{l}\text { Krishnaiah } \\
\text { et } \mathrm{al}^{27}\end{array}$ & India & $\begin{array}{l}7,775 \text { residents of rural } \\
\text { Andhra Pradesh ages I5 } \\
\text { or greater }\end{array}$ & Interview & 28 & 32.9 & 0.5 & \\
\hline $\begin{array}{l}\text { Kumar and } \\
\text { Naik }^{28}\end{array}$ & India & 200 medical students & Survey & 98.2 & 21.1 & & \\
\hline Kumar et $\mathrm{al}^{29}$ & India & $\begin{array}{l}400 \text { medical, nursing, and } \\
\text { paramedical students in } \\
\text { Bhopal }\end{array}$ & Survey & 98 & 46.75 & & \\
\hline
\end{tabular}


Table I (Continued)

\begin{tabular}{|c|c|c|c|c|c|c|c|}
\hline Study & Country & Subjects & Method & $\begin{array}{l}\text { Awareness } \\
\text { (\%) }\end{array}$ & $\begin{array}{l}\text { Willingness } \\
\text { to donate (\%) }\end{array}$ & $\begin{array}{l}\text { Pledged } \\
\text { donors (\%) }\end{array}$ & Comments \\
\hline Lal et $\mathrm{al}^{30}$ & India & $\begin{array}{l}340 \text { health profession } \\
\text { students }\end{array}$ & Survey & 97.9 & 42.6 & & \\
\hline Magdum et $\mathrm{al}^{31}$ & India & 60 paramedical workers & Survey & 75 & 77 & & \\
\hline Nekar et $\mathrm{a}^{32}$ & India & $\begin{array}{l}403 \text { students from } \\
8 \text { colleges }\end{array}$ & Survey & 96 & 78.1 & & \\
\hline Panigrahi et $\mathrm{a}^{33}$ & India & $\begin{array}{l}492 \text { patients and their } \\
\text { attendants awaiting an } \\
\text { appointment at a tertiary } \\
\text { ophthalmology department }\end{array}$ & Survey & 57.9 & 54.6 & & \\
\hline Panigrahi et al ${ }^{34}$ & India & $\begin{array}{l}262 \text { medical and nursing } \\
\text { students }\end{array}$ & Survey & 85.9 & 64.5 & & \\
\hline Patil et $\mathrm{al}^{35}$ & India & 196 adults in rural India & Survey & 80.6 & & & \\
\hline Patil et $\mathrm{al}^{36}$ & India & $\begin{array}{l}\text { I,014 shopkeepers in urban } \\
\text { Pune }\end{array}$ & Interview & 74.16 & 19.83 & & \\
\hline Prabhu $^{37}$ & India & 250 eye clinic patients & Survey & 94.4 & 71.7 & 9.7 & \\
\hline $\begin{array}{l}\text { Priyadarshini } \\
\text { et } \mathrm{al}^{38}\end{array}$ & India & 507 adults in southern India & Interview & 50.7 & & & \\
\hline Ronanki et a ${ }^{39}$ & India & $\begin{array}{l}355 \text { stakeholders, defined as } \\
\text { social services workers and } \\
\text { kin of a cornea donor }\end{array}$ & Interview & 93 & 82 & & \\
\hline Singh et a $\left.\right|^{40}$ & India & $\begin{array}{l}\text { I80 first-year medical } \\
\text { students in Delhi }\end{array}$ & Survey & 99.4 & 87.2 & & \\
\hline Tandon et $\mathrm{al}^{41}$ & India & $\begin{array}{l}\text { I59 next of kin of recently } \\
\text { deceased potential donors } \\
\text { who had not previously } \\
\text { pledged to donate their } \\
\text { corneas }\end{array}$ & Interview & 55.4 & 41.5 & & \\
\hline Tigga et $\mathrm{al}^{42}$ & India & $\begin{array}{l}198 \text { nursing and paramedical } \\
\text { staff }\end{array}$ & Survey & & 21.71 & & $\begin{array}{l}39.39 \% \text { scored } \\
\text { adequately on } \\
\text { knowledge of } \\
\text { eye donation }\end{array}$ \\
\hline Tiwari et al $\left.\right|^{43}$ & India & 947 adults & Interview & 62.3 & & & \\
\hline $\begin{array}{l}\text { Vallinayagam } \\
\text { et al }{ }^{44}\end{array}$ & India & $\begin{array}{l}679 \text { medical and engineering } \\
\text { students }\end{array}$ & Survey & 100 & 84.8 & 3.8 & \\
\hline $\begin{array}{l}\text { Vidusha and } \\
\text { Manjunatha }^{45}\end{array}$ & India & $\begin{array}{l}160 \text { medical students in } \\
\text { Bangalore }\end{array}$ & Survey & 99.3 & & 9 & \\
\hline Bhandary et $\mathrm{al}^{46}$ & Malaysia & $\begin{array}{l}400 \text { patients attending } \\
\text { outpatient appointment }\end{array}$ & Survey & 69 & 34.4 & & \\
\hline Bharti et $\mathrm{al}^{47}$ & Malaysia & $\begin{array}{l}400 \text { university students } \\
\text { studying health sciences }\end{array}$ & Survey & 86 & 27 & & \\
\hline Arya et a ${ }^{48}$ & Nepal & $\begin{array}{l}395 \text { medical and paramedical } \\
\text { staff of a medical institute }\end{array}$ & Survey & 80.5 & 65.4 & & \\
\hline Joshi ${ }^{49}$ & Nepal & $\begin{array}{l}\text { I,775 rural Nepalis age } 15 \\
\text { or older }\end{array}$ & Survey & 30.7 & 32.9 & 0.1 & \\
\hline Abadom et $\mathrm{al}^{50}$ & Nigeria & $\begin{array}{l}\text { I08 medical doctors in } \\
\text { Nigeria }\end{array}$ & Survey & 75.9 & 33.3 & & \\
\hline Eze et $\mathrm{al}^{51}$ & Nigeria & $\begin{array}{l}107 \text { medical students, } \\
75 \text { environmental science } \\
\text { students (controls) }\end{array}$ & Survey & $\begin{array}{l}47.7 \text { (medical } \\
\text { students), } \\
33.3 \text { (controls) }\end{array}$ & $\begin{array}{l}\text { I3.I (medical } \\
\text { students), } \\
\text { I6.0 (controls) }\end{array}$ & & \\
\hline Okoye et a ${ }^{52}$ & Nigeria & $\begin{array}{l}|3| \text { final-year medical } \\
\text { students at the University } \\
\text { of Nigeria }\end{array}$ & Survey & 79.4 & 33.6 & & \\
\hline $\begin{array}{l}\text { Waziri-Erameh } \\
\text { et al }{ }^{53}\end{array}$ & Nigeria & $\begin{array}{l}160 \text { ophthalmologists in } \\
\text { Nigeria }\end{array}$ & Survey & & 21 & & \\
\hline Ahmad et a ${ }^{54}$ & Pakistan & 200 medical students & Survey & 75 & 70 & & \\
\hline Parvez et $\mathrm{al}^{55}$ & Pakistan & I,520 urban Pakistanis & Survey & 65.3 & 7.3 & 1.3 & \\
\hline
\end{tabular}


Table I (Continued)

\begin{tabular}{|c|c|c|c|c|c|c|c|}
\hline Study & Country & Subjects & Method & $\begin{array}{l}\text { Awareness } \\
\text { (\%) }\end{array}$ & $\begin{array}{l}\text { Willingness } \\
\text { to donate (\%) }\end{array}$ & $\begin{array}{l}\text { Pledged } \\
\text { donors (\%) }\end{array}$ & Comments \\
\hline Bugis et $\mathrm{a}^{56}$ & $\begin{array}{l}\text { Saudi } \\
\text { Arabia }\end{array}$ & $\begin{array}{l}374 \text { residents of western } \\
\text { Saudi Arabia }\end{array}$ & Survey & 54.9 & 61.5 & & \\
\hline $\begin{array}{l}\text { Hameed and } \\
\text { Jadidy }{ }^{57}\end{array}$ & $\begin{array}{l}\text { Saudi } \\
\text { Arabia }\end{array}$ & 408 medical students & Survey & 35.8 & 21.1 & & \\
\hline Paraz et a $\left.\right|^{58}$ & Singapore & $\begin{array}{l}500 \text { Singaporean youth } \\
\text { ages } 18 \text { to } 25\end{array}$ & Survey & 26.8 & $\begin{array}{l}31.0(46.8 \\
\text { undecided) }\end{array}$ & & \\
\hline Yew et $\mathrm{al}^{59}$ & Singapore & $\begin{array}{l}544 \text { Singaporean adults at } \\
\text { randomly selected housing } \\
\text { units }\end{array}$ & Interview & 80.7 & 67 & & \\
\hline Palamar et a ${ }^{60}$ & Turkey & $\begin{array}{l}\text { I,000 outpatients awaiting } \\
\text { an appointment }\end{array}$ & Survey & & 54.7 & & \\
\hline \multirow[t]{2}{*}{ Williams et $\mathrm{a}^{61}$} & $\begin{array}{l}\text { United } \\
\text { States }\end{array}$ & $\begin{array}{l}207 \text { patients awaiting } \\
\text { an appointment at a } \\
\text { tertiary eye center and } \\
76 \text { accompanying family } \\
\text { members }\end{array}$ & Survey & & 90 & 11 & \\
\hline & $\begin{array}{l}\text { Total } \\
\text { subjects: }\end{array}$ & 38,851 & Average: & $71 \%$ & $52 \%$ & $5 \%$ & \\
\hline
\end{tabular}

more likely to report being willing to donate compared to ethnic Malays. ${ }^{59}$ In contrast, among outpatients in Malaysia, willingness was higher among those who identified as Indian race compared to those who identified as Chinese. ${ }^{46}$

Although most studies found no association between gender and willingness to donate, male gender has been positively associated with willingness to donate corneas after death in some studies among Chinese and Indian residents. ${ }^{8,33,36}$ Older age has been inconsistently identified as a factor associated with increased willingness to donate. , $39,58^{-10}$ However, Dandona et al and Palamar et al found that older age was associated with decreased willingness to donate, ${ }^{20,60}$ and other studies found no association between age and willingness to donate. ${ }^{9}$

Regarding religion, atheists and non-Muslims had the highest rates of willingness to donate among Singaporean adults, ${ }^{58,59}$ and non-Muslim religion has been associated with increased willingness to donate among other global populations. ${ }^{11,20}$ Higher levels of education are also

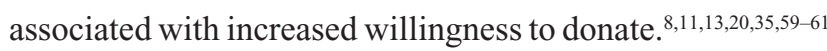
Not surprisingly, being a registered tissue donor was associated with higher levels of willingness to donate corneas after death among a Chinese population. ${ }^{8}$

One modifiable factor associated with increased willingness to donate is awareness about eye donation and knowledge about corneal transplantation, with higher knowledge scores correlating with increased willingness to donate in several studies across different communities in the world. ${ }^{9}, 11-13,58,59$ Survey respondents who indicated that they have discussed eye donation in the past were also more likely to donate. ${ }^{9}$ While surveys of medical professionals generally had higher reported rates of awareness of eye donation, there is room for improvement among this influential population. , $^{4,51,52}$

\section{Learning about eye donation}

Most respondents reported learning about eye donation through television or other media, suggesting a possible outlet for future public health campaigns..$^{13,23,27,30,33,35,36,39,40,46,56}$ Even among medical professionals in India and Nigeria, television and newspapers were the most common source of information about donation, outranking lectures and seminars. 23,26,28,40,51 One survey of secondary school students was an exception, with the most common source of knowledge about corneal donation coming from family, friends, or medical staff followed by media. ${ }^{24}$

\section{Reasons cited for choosing to be an eye donor or not} The most common reasons for being willing to donate include the opportunity to help the blind, ${ }^{12,13,23,24}$ the feeling that eye donation is a noble act, ${ }^{13,23}$ and the thought that eyes are not required after death. ${ }^{24}$

Commonly cited reasons for not being a registered donor or being unwilling to donate include not having had enough information about eye donation to decide or lack of awareness about eye donation, ${ }^{13,23,26,27,33,40,51,57,58,61}$ a desire to keep the body intact after death, ${ }^{12,22-24,39,40,48,58,59,61}$ concerns about family's support of the decision to donate, ${ }^{13,23,24,26,39-41,58,59,61}$ religious objections, ${ }^{13,22,39,48,51,61}$ refusal to discuss the issue, ${ }^{41}$ 
Table 2 Reasons cited for not being willing to donate or not being registered as an eye donor

\begin{tabular}{ll}
\hline Reasons & References \\
\hline $\begin{array}{l}\text { Modifiable reasons } \\
\text { Lack of awareness about eye donation or need }\end{array}$ & $13,23,26,27,33$, \\
$\begin{array}{l}\text { for more information } \\
\text { Feeling that one is too old or unhealthy to donate }\end{array}$ & $40,51,57,58,61$ \\
$\begin{array}{l}\text { Nonmodifiable reasons } \\
\text { Desire to maintain body integrity after death }\end{array}$ & $12,22-24,39,40$, \\
& $48,58,59,61$ \\
Concerns about family's support of the decision & $\mid 3,23,24,26$, \\
to donate & $39-4 \mid, 58,59,61$ \\
Religious objections & $\mid 3,22,39,48,51,61$ \\
Refusal to discuss the issue & $4 \mid$ \\
\hline
\end{tabular}

and feeling that one is too old or unhealthy to donate (Table 2). ${ }^{23,40,51,61}$

\section{Characteristics of registered eye donors}

Several studies have evaluated the characteristics of eye donors. Ranjan et al analyzed the demographic profile of registered eye donors in eastern India. ${ }^{62}$ During a 4 -year period, 743 corneas were retrieved from 373 donors. The mean donor age was 52 years, there were twice as many male compared to female donors, and most common causes of death included cardiorespiratory failure and road traffic accident. Most of the consents to donate were given by sons or daughters of the deceased. Notably, the majority ( $86 \%$ ) of donors were motivated to donate by eye donation counselors, whereas only $14 \%$ were voluntary without this prompting. ${ }^{62}$

At another site in India, Ronanki et al interviewed 50 next of kin of deceased eye donors to understand the motivations of the donors. ${ }^{39}$ They found that $82 \%$ donated without prior pledging and that the family took initiative for donation in $84 \%$ of cases. The reasons individuals elected to donate included feeling that donation is good work and finding satisfaction in giving sight to the blind. ${ }^{39}$

In China, Liu et al evaluated the demographic characteristics of 918 voluntary donors who registered in Beijing Tongren Hospital Eye Bank over a 10-year period. ${ }^{63}$ The authors found that age over 50, female gender, Han race, tertiary-level education, and white collar work were factors that were significantly associated with being a registered donor, which are generally consistent with factors associated with expressed willingness to donate. In a separate survey of registered tissue donors in Nanjing, China, Chu et al identified characteristics that differed between registered donors and control residents. ${ }^{8}$ Tissue donors had better knowledge about the donation process, had less misconception about disfigurement from corneal retrieval, and were significantly more likely to have discussed donation with their family. ${ }^{8}$

\section{Eye donation for research}

While the general emphasis of survey studies on attitudes about eye donation has focused on the need for corneal tissue for clinical transplantation, it is also notable that there is a tremendous unmet need for eye tissue for research. ${ }^{64}$ Donor tissue is particularly critical for research on eye diseases that occur primarily in humans, such as age-related macular degeneration and open-angle glaucoma. Unfortunately, the availability of eye tissue for researchers has been declining. ${ }^{65}$ Statistics compiled by the Eye Bank Association of America demonstrate a continued downward trend of both the proportion and the total number of eye tissues distributed for research in the United States. Specifically, in 2016, 12.5\% of a total of 136,318 total whole eyes and corneas donated were distributed for research, which is down from $16.5 \%$ of 116,990 donor eyes in 2012. ${ }^{66}$ Researchers have expressed concerns about the declining availability of human eye tissue to pursue their study of blinding diseases. ${ }^{64}$

Efforts to ameliorate the critical shortage of tissue for research have included increasing communication with eye patients about the opportunity to donate for research and fostering collaborations with local eye banks. Eye tissue used for research generally does not qualify for corneal transplantation due to presence of disease or advanced age, allowing pursuit of parallel goals to recruit eye donors for transplant and research use. Pilot survey studies suggest support for eye donation for research among eye patients and eye care providers, including the appropriateness of bringing up the topic at clinic appointments. ${ }^{61,67}$ Among Australian patients with age-related macular degeneration, a 15-minute counseling session about eye donation led to a greater interest in donating for $68 \%$ of patients interviewed, particularly for the purpose of research on their disease. ${ }^{68}$ Along the same lines, a proposed, prospective eye donation registry for research was generally well received among a population of ophthalmic patients, with $55 \%$ of those surveyed willing to consider joining the hypothetical donor list, suggesting unmet potential to recruit prospective donors. ${ }^{61}$ Additionally, collaborative programs between academic centers and eye banks have been proposed to ensure that individuals with a wish to donate for research would have their eyes procured despite not qualifying for clinical transplant use. ${ }^{69}$ As interventions increase awareness about eye donation in general, more opportunities will arise to discuss the possibility of donating for research with patients who may have a wish to do so.

\section{Interventions to increase donor rates}

A common theme across the included studies is that few respondents were registered donors, but many had positive 
views toward eye donation and expressed willingness to donate their eyes. For instance, Dandona et al found that $44.9 \%$ of urban Indian adults surveyed were willing to donate their eyes, but only $1.9 \%$ were registered ${ }^{20}$ Similar findings were noted in a survey of rural Indian adults, with $32.9 \%$ willing to donate but only $0.5 \%$ had pledged their eyes. ${ }^{27}$ This same pattern was also noted among rural Nepalis and patients in the United States. ${ }^{49,61}$ The disconnect between having an interest in donating and being registered to donate suggests an unmet potential to recruit more eye donors.

\section{Media campaigns}

Informational media campaigns about eye donation and the process to register as a donor could be an effective intervention to increase donor rates, especially given that television and newspapers are the most commonly cited sources of information on donation. Knowledge about corneal donation is a factor positively associated with willingness to donate, and knowledge scores on the donation process have been generally low across several studies, even among health professionals. ${ }^{21,40,48,52}$ Further demonstrating the general lack of knowledge of corneal donation, only half (58\%) of cornea recipients in Israel were aware that the graft came from a deceased person. ${ }^{70}$ It is also notable that the majority of respondents in various surveys were unaware about how to become an eye donor, ${ }^{8,10,21}$ and needing more information was the most commonly cited reason for not being a registered donor across multiple studies. Increasing knowledge about eye donation and informing the public about the process of registering to pledge one's eyes after death through media campaigns could tap into the tremendous unmet potential of those who are willing to donate their eyes but are unaware of the process, ${ }^{71}$ as long as these interventions are carefully designed to communicate accurate information while minimizing bias. ${ }^{72}$

\section{Education initiatives for medical staff}

Several interventions to increase eye donor rates have been published in the literature. At the University of Iowa, a retrospective review found that 12 of the last 50 consecutive deaths at the cardiovascular intensive care unit could have qualified as cornea donors, but only one donated eyes after death. ${ }^{73}$ Nurses and house staff cited not thinking to ask as the most commonly cited obstacle to procurement. In order to increase rates of donation, a 30-minute in-service education session was held with nurses and house staff to review transplantation eligibility criteria and logistics of eye donation. The authors found that procurement of transplantable corneas doubled the year after the intervention to 42 compared to average of 22 per year during the 3 years prior. This study highlights the benefits of collaborative efforts with intensive care staff in facilitating discussion of eye and organ donation at the end of life.

\section{Involvement of grief counselors and religious leaders}

Similarly, the use of grief counselors in intensive care units in India has been associated with a significant increase in eye donation. Counselors play a particularly important role in providing discussion about eye donation with next of kin, for whom lack of information on the topic leads to high rates of procurement refusal. ${ }^{74,75}$ Sharma et al conducted a prospective study in which grief counselors identified 554 critically ill patients and discussed the topic of eye donation with their families. ${ }^{76}$ In a follow up survey, the grief counselors had the largest influence on the decision to donate. In a separate pilot intervention, counselors from a regional eye bank were notified of every hospital death and reached out to the next of kin to discuss the possibility of eye donation. This intervention resulted in a $68 \%$ increase in cornea donations compared to the pre-intervention phase. ${ }^{77}$ Further highlighting the importance of grief counselors in promoting eye donation, a review of eye tissue donors in India found that grief counselors motivated a total of $86 \%$ of donors. ${ }^{62}$ The use of eye donation counselors, while resource intensive, can significantly increase the conversion rate for corneal donors.

Given the cultural sensitivity of pledging eyes at the end of life, the involvement of religious leaders has been demonstrated to increase willingness to donate eyes after death. Gogate et al enlisted the help of local priests to discuss the importance of giving and the opportunity of eye donation when giving the last rites to a dying family member. ${ }^{78}$ The incorporation of the discussion of eye donation in the context of religious ritual increased the number of corneas collected from none in the year before implementation to 254 during the first year of the program.

\section{Interventions from the organ donation literature}

Inquiring about donation registration at government offices

Insights on interventions to increase donor rates can also be gleaned from the larger literature on organ and tissue donation. In the United States, nearly all registered organ and tissue donors joined the registry through their local Department of Motor Vehicles (DMV) office, which issues drivers' licenses. ${ }^{79}$ Additional education and motivational sessions with clerks at these offices has yielded yet higher donor rates, ${ }^{79-81}$ and the inclusion of an informative video about 
organ donation at the time of DMV appointment has increased donor rates among minority groups. ${ }^{82}$ The incorporation of a prompt for organ, eye, and tissue donation at government offices may have similar success in other countries as long as varying cultural norms are adequately addressed.

\section{Social media}

The use of social media has been a recent development for communicating about one's intention to donate across a social network. Cameron et al describe the positive effects on organ donor registration following the decision by Facebook, a social media website, to allow users to designate "organ donor" as part of their user profile. ${ }^{83}$ After making this designation, users in the United States are given a link to their state registry to complete the registration process, and their social media contacts are made aware of this status update. On the first day of this initiative, there was a 21-fold increase in new online organ and tissue donor registrations compared to baseline, where there was no increase in registrations at the DMV over this timeframe. In another Facebook initiative, Kumar et al collaborated with the social media company to design a mobile application (or app) as a platform for those awaiting organ transplant to communicate their personal story. ${ }^{84}$ Compared to a control group, those who used the app were 6 times more likely to have a living donor come forward on their behalf. As more of the world becomes connected to the Internet, online registration and promotion through social media platforms is a promising opportunity to increase donor rates for solid organs and eye tissues alike.

\section{Medical school coursework}

Dedicating coursework for medical students about organ donation has led to increased knowledge about the organ donation process at two American universities. ${ }^{85,86}$ Although levels of awareness about eye donation are generally higher among medical professionals compared to the general population, knowledge scores were generally modest, suggesting an opportunity for education intervention among this influential group. ${ }^{48,51,52}$

\section{Limitations}

There are several limitations to this review. First, research methods vary greatly between included studies, particularly regarding question wording and interview methods. In particular, differences in question wording, such as asking if one is willing to donate her eyes versus asking if she is willing to consider eye donation, could lead to substantial variation in responses. Along the same lines, there are major differences between the three main outcome measures selected for this review: awareness about eye donation, willingness to donate, and self-reported status as a registered eye donor. Due to variation in study designs, all three outcomes were rarely reported in a given article, and few surveys inquired about self-reported status as a pledged donor. Furthermore, this review is unable to examine the exact relationship between awareness about eye donation and expressed willingness to donate due to variation in study designs. While this review aims to include a wide range of studies about attitudes on eye donation, the heterogeneity of study designs does limit direct comparisons between studies. Second, there is overrepresentation of a small number of countries among the included studies. In particular, a large body of the work reviewed in this paper was conducted in the developing world, with a disproportionate number conducted in India in particular, which may limit applicability of these findings elsewhere. For instance, attitudes about eye donation and potential interventions to increase donor rates may differ between areas of the world with a history of infrastructure for eye banking and organ donation compared to areas that are still growing these programs.

\section{Conclusions}

A large body of research has surveyed awareness of eye donation and willingness to donate eyes in various global populations. In general, respondents have favorable views toward eye donation, and many more have indicated a willingness to donate than have pledged to be donors. The most commonly cited reasons for not being a registered donor are lack of awareness about eye donation and not knowing how to pledge one's eyes for donation after death. These characteristics indicate tremendous potential for drastically increasing the number of registered eye donors worldwide through educational campaigns. Additionally, collaborations with medical personnel to identify potential donors and culturally sensitive interventions between grief counselors and next of kin have led to increased donor rates by informing decision-makers of the opportunity to donate eyes after death. Finally, successful interventions from the larger organ donation literature may also be incorporated to increase eye donation rates, including the integration of organ registration with local government offices, the use of social media platforms, and educational interventions for medical students. With the current severe shortage of one cornea available for every 70 needed worldwide, ${ }^{6}$ there is a strong impetus for further interventions and research to tap into the tremendous unmet potential of willing but unregistered eye donors. 


\section{Disclosure}

The authors report no conflicts of interest in this work.

\section{References}

1. Pascolini D, Mariotti SP. Global estimates of visual impairment. Br J Ophthalmol. 2012;96(5):614-618.

2. Liang YB, Friedman DS, Wong TY, et al. Prevalence and causes of low vision and blindness in a rural Chinese adult population: the Handan Eye Study. Ophthalmology. 2008;115(11):1965-1972.

3. Xu L, Wang Y, Li Y, et al. Causes of blindness and visual impairment in urban and rural areas in Beijing: the Beijing Eye Study. Ophthalmology. 2006;113(7):1134-1141.

4. Dandona L, Dandona R, Srinivas M, et al. Blindness in the Indian state of Andhra Pradesh. Invest Ophthalmol Vis Sci. 2001;42(5):908-916.

5. Hong J, Shi W, Liu Z, et al. Limitations of keratoplasty in China: a survey analysis. PLoS One. 2015;10(7):e0132268.

6. Gain P, Jullienne R, He Z, et al. Global survey of corneal transplantation and eye banking. JAMA Ophthalmol. 2016;134(2):167-173.

7. Lawlor M, Kerridge I, Ankeny R, Dobbins TA, Billson F. Specific unwillingness to donate eyes: the impact of disfigurement, knowledge and procurement on corneal donation. Am J Transplant. 2010;10(3):657-663.

8. Chu T, Wang LN, Yu H, Zhang RY. Awareness of cornea donation of registered tissue donors in Nanjing. Chin Med Sci J. 2013;28(1):20-27.

9. Wang X, Jin L, Wang J, et al. Attitudes and knowledge concerning corneal donation in a population-based sample of urban Chinese adults. Cornea. 2016;35(10):1362-1367.

10. Zhao M, Li H, Yang J, Xu ZY, Peng JC, Wang GJ. 重庆市角膜捐献人 群的现状分析 [An investigation of current situation of corneal donors action in Chongqing]. Zhonghua Yan Ke Za Zhi. 2003;39(7):422-426. Chinese [with English abstract].

11. Gelaw Y, Ambaw F. Socio-demographic correlates of attitude towards corneal donation among health science students and academic staff of Jimma University. Ethiop Med J. 2010;48(1):41-47.

12. Gessesse GW, Tilahun Y. Willingness to donate eyes and associated factors among adults in a rural community in Central Ethiopia. J Ophthalmol East Cen South Africa. 2013;17(1):20-24.

13. Hussen MS, Gebreselassie KL, Woredekal AT, Adimassu NF. Willingness to donate eyes and its associated factors among adults in Gondar town, North West Ethiopia. BMC Ophthalmol. 2017;17(1):178.

14. Ackuaku-Dogbe EM, Abaidoo B. Eye donation: awareness and willingness among patients attending a tertiary eye center in Ghana. West Afr J Med. 2014;33(4):258-263.

15. Acharya M, Chaku D, Dave A, Das A, Patel NV. Knowledge and attitude toward corneal donation among high school children in northern India. Cornea. 2018;37(1):e2-e3.

16. Ahirwar RK, Shidhaye PR, Ekka IJ, Saxena DM. Study of knowledge and willingness regarding eye donation among medical students of a tertiary care teaching hospital of central India. Int J Community Med Public Health. 2016;3(9):2363-2368.

17. Amruth M, Kulkarni AG, Kamble SV, Borker SA, Rekha R, Ismail IM. Awareness and perception regarding eye donation among adult patients and their attendants in a primary health centre, South India. Int J Health Sci Res. 2014;4(9):1-8.

18. Biswas J, Bandyopadhyay S, Das D, Mondal KK, Saha I, Ray B. A study on awareness about eye health care and eye donation among secondary level students of North Kolkata, India. Kathmandu Univ Med J (KUMJ). 2010;8(31):317-320.

19. Chacko HM, Mathew J, Jose J, Dominic J. Knowledge and attitude regarding eye donation among the adolescents: a co-relational study. Nitte Univ J Health Sci. 2014;4(1):66-71.

20. Dandona R, Dandona L, Naduvilath TJ, McCarty CA, Rao GN. Awareness of eye donation in an urban population in India. Aust $N Z J$ Ophthalmol.1999;27(3-4):166-169.

21. Dhaliwal U. Enhancing eye donation rates. Training students to be motivators. Indian J Ophthalmol. 2002;50(3):209-212.
22. Duggal M, Brar GS, Prasad VS, Gupta A. Public attitudes toward eye donation in Northwestern India. Transplant Proc. 2003;35(1):19-20.

23. Gupta A, Jain S, Jain T, Gupta K. Awareness and perception regarding eye donation in students of a nursing college in Bangalore. Indian $J$ Community Med. 2009;34(2):122-125.

24. Gupta PC, Duggal M, Jamir L, et al. Knowledge and attitude toward corneal donation among high school children in northern India. Cornea. 2017;36(5):611-616.

25. Khan N, Agrawal PC, Tigga M, Saini VK, Gupta S. Level of awareness regarding eye donation among patients attending eye OPD at tertiary hospital. Natl J Community Med. 2015;6(2):70-73.

26. Khandelwal R, Katre P. Perception and awareness about eye donation in health-care providers in central India: challenges and solutions. $J$ Evid Based Med. 2015;2(44):8066-8073.

27. Krishnaiah S, Kovai V, Nutheti R, Shamanna BR, Thomas R, Rao GN. Awareness of eye donation in the rural population of India. Indian $J$ Ophththalmol. 2004;52(1):73-78.

28. Kumar MP, Naik BS. To assess the knowledge of the undergraduate medical students regarding eye donation. Int J Res Health Sci. 2013; 1(3):244-247.

29. Kumar S, Shukla US, Agarwal P. Awareness and knowledge on eye donation among students at Bhopal. Natl J Community Med. 2012;3(4): 685-689.

30. Lal B, Usgaonkar U, Narvekar H, Venugopal D. Awareness and knowledge on eye donation among allied health sciences, medical, and nursing students in Goa. J Current Ophthalmol. Epub 2018 Mar 7.

31. Magdum R, Arun S, Mushtaq I, Sharma N. To study awareness and willingness of eye donation among paramedical workers. J Clin Ophthalmol Res. 2015;3(2):95-97.

32. Nekar MS, Lokare L, Gokhale SA, Godbole M, Mulkipatil SY, MaHesh V. Awareness of eye donation among college students of Hubli City, Karnataka. Int J Biomed Res. 2012;3(4):201-204.

33. Panigrahi S, Rath B, Sahu RK, Rath S, Sethi SK, Mahapatra K. Knowledge, attitude and willingness for eye donation in general population of Odisha in eastern India. IOSR J Dent Med Sci. 2017; 16(7):1-6.

34. Panigrahi S, Sahu RK, Rath B, Rath S, Padhi S, Mekup CK. Knowledge, attitude and willingness about eye donation among medical and nursing students in a medical college hospital of southern Odisha. Sch J App Med Sci. 2017;5(7A):2545-2551.

35. Patil R, Prasath ER, Boratne A, Gupta SK, Datta SS. Status of eye donation awareness and its associated factors among adults in rural Pondicherry. J Clin Diagn Res. 2015;9(2):LC01-LC04.

36. Patil R, Gothankar J, Bhat P, Saluja J, Sane S. Eye donation: awareness and willingness among shopkeepers. Int J Community Med Public Health. 2017;4(6):2056-2059.

37. Prabhu PB. Concerns regarding eye donation among health seekers attending a reputed eye care institution in North Kerala. Kerala $J$ Ophthalmol. 2016;28:43-47.

38. Priyadarshini B, Srinivasan M, Padmavathi A, Selvam S, Saradha R, Nirmalan PK. Awareness of eye donation in an adult population of southern India. A pilot study. Indian J Ophthalmol. 2003;51(1):101-104.

39. Ronanki VR, Sheeladevi S, Ramachandran BP, Jalbert I. Awareness regarding eye donation among stakeholders in Srikakulam district in South India. BMC Ophthalmol. 2014;14:25.

40. Singh MM, Rahi M, Pagare D, Ingle GK. Medical students' perception on eye donation in Delhi. Indian J Ophthalmol. 2007;55(1):49-53.

41. Tandon R, Verma K, Vanathi M, Pandey RM, Vajpayee RB. Factors affecting eye donation from postmortem cases in a tertiary care hospital. Cornea. 2004;23(6):597-601.

42. Tigga MJ, Agarwal PC, Gupta S, et al. Level of awareness and attitude regarding eye donation amongst nursing and paramedical staff working in tertiary care centre. J Evid Based Med. 2016;3(44):2189-2193.

43. Tiwari R, Diwakar A, Marskole P, Bhargo L, Anwar D. A study to assess awareness on eye donation and willingness to pledge eyes for donation in adult population in Gwalior district (MP), India. J Res Med Sci. 2014;2(2):662-666. 
44. Vallinayagam M, Kumar PS, Krishnamoorthy J, Arumugam R. A study on eye donation awareness among medical and engineering students in Puducherry. Dehli J Ophthalmol. 2017;28:20-24.

45. Vidusha K, Manjunatha S. Awareness of eye donation among medical students of tertiary care hospital, Bangalore. Asian Pac J Health Sci. 2015;2(2):94-98.

46. Bhandary S, Khanna R, Rao KA, Rao LG, Lingam KD, Binu V. Eye donation-awareness and willingness among attendants of patients at various clinics in Melaka, Malaysia. Indian J Ophthalmol. 2011;59(1): $41-45$.

47. Bharti MK, Reddy SC, Tajunisah I, Ali NA. Awareness and knowledge on eye donation among university students. Med J Malaysia. 2009; 64(1):41-45.

48. Arya SK, Gupta N, Malik A. Eye donation awareness among medical and paramedical staff in a medical institute. Nepal J Ophthalmol. 2014; 6(2):177-184

49. Joshi SD. Eye donation awareness among community people in Nepal. Transplantation. 2010;90:557. (Abstract).

50. Abadom EG, Otene CI, Enivwenae AO. Knowledge and willingness to donate eye among medical doctors in delta state. IOSR J Dent Med Sci. 2014;13(6):57-63.

51. Eze BI, Okoye O, Eze JN. Knowledge and attitudes regarding eye donation and corneal transplant: medical versus nonmedical university students in a developing country in Africa. Exp Clin Transplant. 2014; 12(5):454-461.

52. Okoye O, Maduka-Okafor FC, Eze BI. What does the medical student know about eye donation/corneal transplant? The University of Nigeria scenario. West Ind Med J. 2010;59(1):41-44.

53. Waziri-Erameh JM, Ernest AO, Edema OT. Knowledge and attitude of Nigerian ophthalmologists towards cornea donation and corneal graft. J Med Biomed Res. 2007;6(1-2):26-34.

54. Ahmad S, Ali M, Afzal M. Knowledge and attitudes toward corneal donation amongst medical students in University of Lahore (a crosssectional study). Ophthalmology Update. 2018;16(1):465.

55. Parvez MA, Alvi S, Mahida K, et al. Eye donation: awareness in urban population of Pakistan: an analysis. APMC. 2016;10(3):142-146.

56. Bugis A, Ali A, Almaghrabi A, et al. Knowledge and attitudes regarding eye donation and corneal transplants in Saudi Arabia: A cross-sectional study. Int J Med Health Res. 2018;4(2):6-9.

57. Hameed N, Jadidy E. Knowledge and attitude regarding eye donation and corneal transplantation among medical students of Taibah University in Medina, Saudi Arabia 2015. Int J Acad Sci Res. 2015;3(4):18-26.

58. Paraz CM, Truong HT, Sai DK, Cajucom-Uy HY, Chan CL, Kassim SM. Knowledge and attitudes toward corneal donation among Singaporean youth: a cross-sectional study. Eye Vis. 2016;3(1):17.

59. Yew YW, Saw SM, Pan JC, et al. Knowledge and beliefs on corneal donation in Singapore adults. Br J Ophthalmol. 2005;89(7):835-840.

60. Palamar M, Durusoy R, Egrilmez S, Salis O, Yagci A. Public opinion concerning corneal donation and transplant: a survey from Izmir, Turkey. Exp Clin Transpl. 2011;9(2):134-138.

61. Williams AM, Allingham RR, Beckwith HS, Liu PJ, Santiago-Turla C, Muir KW. Patient and family attitudes about an eye donation registry for research. Curr Eye Res. 2013;38(9):945-951.

62. Ranjan A, Das S, Sahu SK. Donor and tissue profile of a community eye bank in Eastern India. Indian J Ophthalmol. 2014;62(9):935-937.

63. Liu Y, Zhang YN, Zhang J, Li AP, Liang QF, Pan ZQ. Demographic characteristics of voluntary donors registered in Beijing Tongren Hospital Eye Bank of China: a retrospective study from 2007 to 2016. Transplant Proc. 2017;49(8):1712-1718.

64. Williams AM, Stamer WD, Allingham RR. Increasing the availability and quality of donor eyes for research. JAMA Ophthalmol. 2016; 134(4):351-352.

65. Curcio CA, Research Tissue Acquisition Working Group. Declining availability of human eye tissues for research. Invest Ophthalmol Vis Sci. 2006;47(7):2747-2749.
66. Eye Bank Association of America. 2016 Eye Banking Statistical Report. 2017. Available from: http://restoresight.org/wp-content/ uploads/2017/04/2016_Statistical_Report-Final-040717.pdf. Accessed March 25, 2018.

67. Williams AM, Allingham RR, Stamer WD, Muir KW. Eye care professionals' perspectives on eye donation and an eye donation registry for research: a single-institution, cross-sectional study. Curr Eye Res. 2016;41(6):867-871.

68. Zhu M, Syed A, Joachim ND, Luo K, Petsoglou C, Chang AA. Evaluation of a direct approach to eye donation in a population with retinal diseases. Invest Ophthalmol Vis Sci. 2014;55(13):681.

69. Williams AM, Perkumas KM, Perry I, et al. Successful implementation of a program for increasing donor eyes for research: the DukeMiracles in Sight Program. J Ocul Pharmacol Ther. 2016;32(3): 145-149.

70. Abuksis G, Orenstein S, Hershko A, et al. Cornea recipients: are their opinions and attitudes toward organ donation different from those of the general population? Transplant Proc. 2004;36(5):1249-1252.

71. Feeley TH, Tamburlin J, Vincent DE. An educational intervention on organ and tissue donation for first-year medical students. Prog Transplant. 2008;18(2):103-108.

72. Rady MY, McGregor JL, Verheijde JL. Mass media campaigns and organ donation: managing conflicting messages and interests. Med Health Care and Philos. 2012;15(2):229-241.

73. Mack RJ, Mason P, Mathers WD. Obstacles to donor eye procurement and their solutions at the University of Iowa. Cornea. 1995;14(3): 249-252.

74. Prous M, Ponto M. Barriers to ocular tissue donation in acute clinical settings. Prog Health Sci. 2015;5(2):134-141.

75. Hermann KC, Pagnussato F, Franke CA, de Oliveira ML. Reasons for family refusal of ocular tissue donation. Transplant Proc. 2014; 46(6):1669-1671.

76. Sharma B, Shrivastava U, Kumar K, Baghel R, Khan F, Kulkarni S. Eye donation awareness and conversion rate in hospital cornea retrieval programme in a tertiary hospital of central India. J Clin Diagn Res. 2017; 11(8):NC12-NC15.

77. Pandey NU, Gupta AK, Jain AK, Koushal V, Bindra N, Minz C. Can eye donation rates be increased in hospitals: a pilot study in a tertiary care hospital in North India? Public Health. 2016;136:141-143.

78. Gogate B, Gogate P, Deshpande M. Eye donation programme through faith leaders. Br J Ophthalmol. 2008;92(6):867-868.

79. Rodrigue JR, Krouse J, Carroll C, Giery KM, Fraga Y, Edwards E. A Department of Motor Vehicles intervention yields moderate increases in donor designation rates. Prog Transplant. 2012;22(1):18-24.

80. Harrison TR, Morgan SE, Corcia MJ. Effects of information, education, and communication training about organ donation for gatekeepers: clerks at the Department of Motor Vehicles and organ donor registries. Prog Transplant. 2008;18(4):301-309.

81. Harrison TR, Morgan SE, King AJ, Williams EA. Saving lives branch by branch: the effectiveness of driver licensing bureau campaigns to promote organ donor registry sign-ups to African Americans in Michigan. J Heath Commun. 2011;16(8):805-819.

82. Thornton JD, Alejandro-Rodriguez M, León JB, et al. Effect of an iPod video intervention on consent to donate organs: a randomized trial. Ann Intern Med. 2012;156(7):483-490.

83. Cameron AM, Massie AB, Alexander CE, et al. Social media and organ donor registration: the Facebook effect. Am J Transplant. 2013; 13(8):2059-2065.

84. Kumar K, King EA, Muzaale AD, et al. A smartphone app for increasing live organ donation. Am J Transplant. 2016;16(12):3548-3553.

85. Feeley TH, Moon SI. A meta-analytic review of communication campaigns to promote organ donation. Commun Rep. 2009;22(2):63-73.

86. Essman CC, Lebovitz DJ. Donation education for medical students: enhancing the link between physicians and procurement professionals. Prog Transplant. 2005;15(2):124-128. 
Clinical Ophthalmology

\section{Publish your work in this journal}

Clinical Ophthalmology is an international, peer-reviewed journal covering all subspecialties within ophthalmology. Key topics include: Optometry; Visual science; Pharmacology and drug therapy in eye diseases; Basic Sciences; Primary and Secondary eye care; Patien Safety and Quality of Care Improvements. This journal is indexed on

Submit your manuscript here: http://www.dovepress.com/clinical-ophthalmology-journal

PubMed Central and CAS, and is the official journal of The Society of Clinical Ophthalmology (SCO). The manuscript management system is completely online and includes a very quick and fair peer-review system, which is all easy to use. Visit http://www.dovepress.com/ testimonials.php to read real quotes from published authors. 